\title{
Geochronology of Granites, Surrounding Schists and Ores of the Panimba Gold Deposit (the Yenisey Ridge)
}

\author{
Anatoly M. Sazonov*a, Natalja A. Nekrasova ${ }^{a}$, \\ Elena A. Zvyagina ${ }^{a}$ and Platon A. Tishin ${ }^{b}$ \\ ${ }^{a}$ Siberian Federal University \\ 79 Svobodny, Krasnoyarsk, 660041, Russia \\ ${ }^{b}$ Tomsk State University \\ 36 Lenin Str., Tomsk, 634050, Russia
}

Received 25.06.2015, received in revised form 17.09.2015, accepted 21.02.2016

Data of isotope geochronological researches of zircons by $U$-Pb method, also results of Ar-Ar method researches of muscovites from the gold-bearing ores, surrounding schists and granites of the Panimba gold deposit in the Yenisey Ridge are presented. Regional metamorphism of the lower Riphean Kordinskaya suite terrigene sediments, containing ore bodies, took place in the interval of 996,0 $032-889,0 \pm 26,6 \mathrm{Ma}$. The graniteforming and contact metamorphism of schists

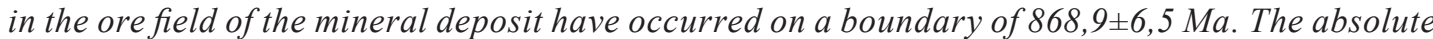
age of the quartz gold sulphide orebearing veins lies in the interval of 817,2 $\pm 5,3-744 \pm 17 \mathrm{Ma}$

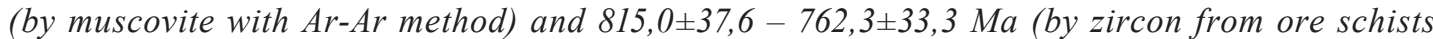
with U-Pb method). The long history of development of the Yenisei Range from Upper Archean to Upper Paleozoic was reflected in an accessory zircon of ore schists.

Keywords: U-Pb dating, Ar-Ar dating, Panimba gold deposit, Yenisei Range.

Citation: Sazonov A.M., Nekrasova N.A., Zvyagina E.A., Tishin P.A. Geochronology of granites, surrounding schists and ores of the Panimba gold deposit (the Yenisey Ridge), J. Sib. Fed. Univ. Eng. technol., 2016, 9(2), 174-188, DOI: 10.17516/1999-494X-2016-9-2-174-188.

(c) Siberian Federal University. All rights reserved

* Corresponding author E-mail address: sazonov am@mail.ru 


\title{
Геохронология гранитов, вмещающих сланщев
}

\section{и руд месторождения золота «Панимба» (Енисейский кряж)}

\author{
А.М. Сазонов ${ }^{\text {a }}$, Н.А. Некрасова ${ }^{a}$, \\ Е.А. Звягина ${ }^{a}$, П.А. Тишин \\ ${ }^{a}$ Сибирский федеральный университет \\ Россия, 660041, Красноярск, пр. Свободный, 79 \\ ${ }^{6}$ Томский государственный университет \\ Россия, 634050, Томск, пр. Ленина, 36
}

Приведены изотопные геохронологические исследования U-Pb иирконов и Ar-Ar мусковита золотоносных руд, вмещающих сланщев и гранитов золоторудного месторождения «Панимба» в Енисейском кряже. Региональный метаморфизм песчано-алеврито-глинистых отложений кординской свиты нижнего рифея, вмещающей рудные тела, проходил в интервале 996,0土32 889,0 26,6 млн лет. Гранитообразование и контактовый метаморфизм сланцев в рудном поле

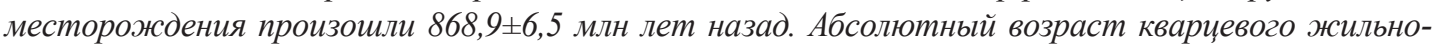
прожилкового золото-сульфидно-вкрапленного оруденения лежит в интервале 817,2 $\pm 5,3$ -

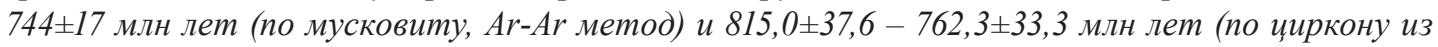
рудного сланца, U-Pb-метод). В акцессорном иирконе рудного сланца отразилась длительная история развития Енисейского кряжа, начиная с верхнего архея до верхнего палеозоя.

Ключевые слова: U-Pb-, Ar-Ar-датирование, месторождение золота «Панимба», Енисейский кряж.

\section{Введение}

Золоторудное месторождение «Панимба» расположено в центре Восточного золотоносного пояса Енисейского кряжа, в бассейне рек Панимба и Чиримба, являющихся правыми притоками р. Большой Пит (рис. 1). В регионе ведутся эксплуатационные работы на месторождениях «Советское», «Эльдорадо», «Олимпиада», «Благодатное», «Александро-Агеевское», «Васильевское», «Герфед», «Николаевское», «Удерейское», «Бабушкина гора». В разведочных и эксплуатационных выработках последних лет появился новый геологический материал, позволяющий расширить представления о генетических аспектах золоторудогенеза в метаморфических толщах.

До настоящего времени для месторождений региона не сформировалось однозначного мнения об особенностях генетической связи рудообразования с гранитоидным магматизмом $[1,5]$, метаморфизмом [2] или седиментогенезом [7]. По материалам изотопно-геохронологических исследований последних лет В.А. Верниковского, А.Д. Ножкина, М.И. Волобуева, А.М. Сазонова, А.А. Томиленко, Л.В. Ли, И.И. Лиханова, В.Г. Петрова, Ф.П. Кренделева, А.Е. Верниковской, П.А. Неволько, А.С. Борисенко, гранитоидный магматизм в золотоносном поясе Енисейского кряжа проявился в интервале 1000-625 млн лет назад, метаморфогенно-метасоматические образования в пределах рудных полей имеют возраст 890-775 млн лет, золоторудная минерализация - 830-680 млн лет, антимонитовая - 676,6-605 млн лет [8]. Широкий разброс и перекрытие значений абсолютного возраста позволяют вольно трактовать связь оруденения либо с гранитоидным магматизмом, либо метаморфизмом. Еще более сложным является обоснованиеотрицание седиментогенной природы формирования концентраций золота, так как можно пред- 


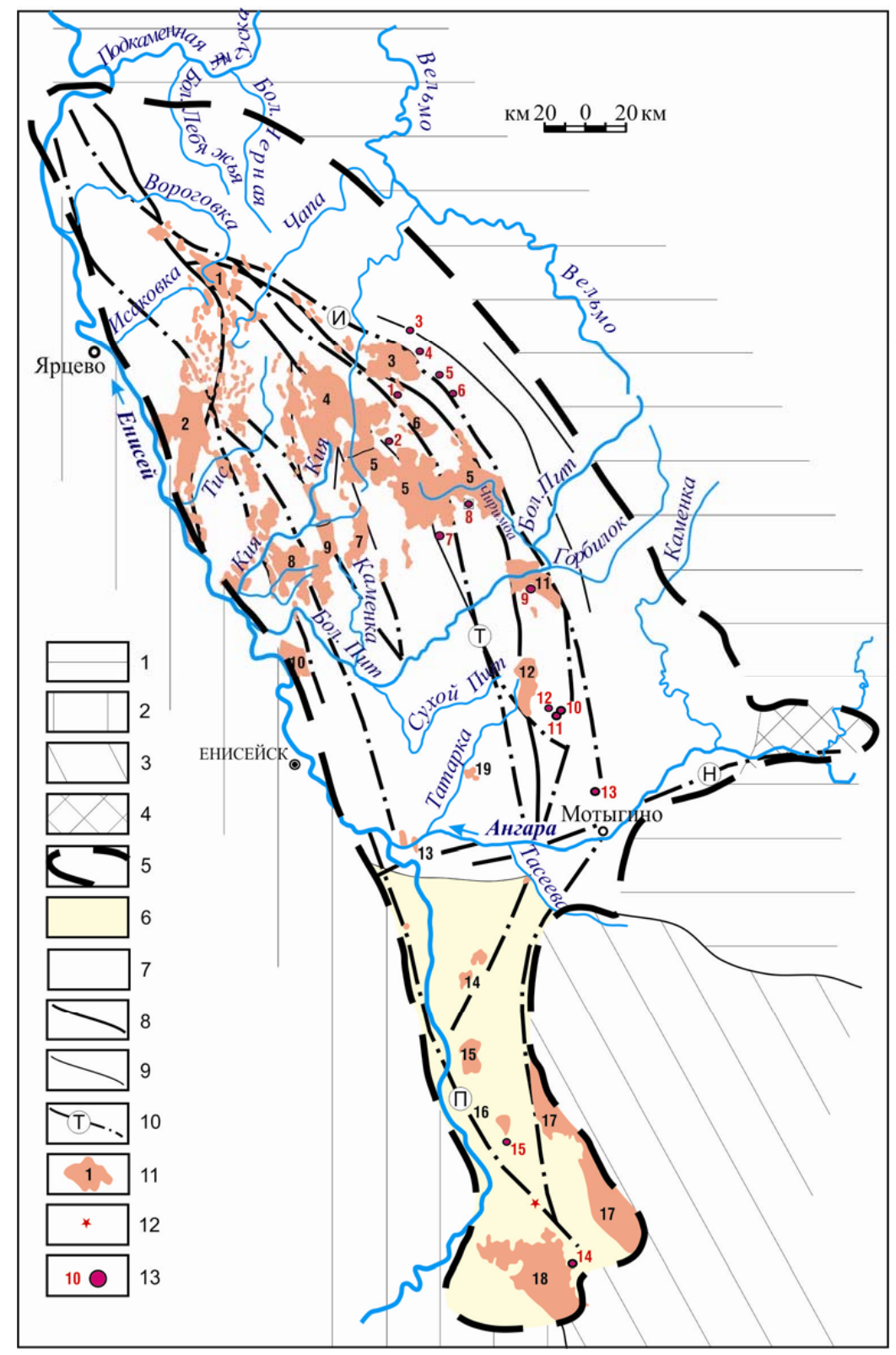

Рис. 1. Положение золоторудных месторождений в структурах Енисейского кряжа: 1 - Сибирская платформа; 2 - Западно-Сибирская плита; 3 - Канско-Тасеевская впадина; 4 - Иркинеевский авлакоген; 5 - 13 - Енисейский кряж: 5 - граница Енисейского кряжа; 6 - Ангаро-Канский выступ архея (ЮжноЕнисейский кряж); 7 - Байкальская складчатая область (Заангарская часть Енисейского кряжа); 8 - оси антиклиналей тейской серии (нижний протерозой); 9 - оси антиклиналей кординской свиты сухопитской серии (нижний рифей); 10 - региональные разломы: И-Ишимбинский, Т-Татарский, П-Приенисейский, Н - Нижнеангарский; 11 - массивы гранитоидов и фельдшпатоидных пород: 1 - Исаковский, 2 - Гаревский, 3 - Каламинский, 4 - Тейский, 5 - Чиримбинский, 6 - Гурахтинский (Ерудинский, по Ф.П. Кренделеву), 7 - Лендахский, 8 - Киликейский, 9 - Гремихинский, 10 - Чернореченский, 11 - Аяхтинский, 12 - Татарский, 13 - Стрелковский, 14 - Чистопольский, 15 -Посольненский, 16 -Белогорский, 17 - Таракский, 18 - Нижне-Канский, 19 - Средне-Татарский массив ийолитов и фельдшпатоидных сиенитов; 12 -палеовулкан Севернинский (трахиты, риолиты, микрограниты, микросиениты); 13 - золоторудные месторождения: 1 - Благодатное, 2 - Олимпиада, 3 - Советское, 4 - Александро-Агеевское, 5 - Пролетарское, 6 - Эльдорадо, 7 - Ведугинское, 8 - Панимба, 9 - Аяхтинское, 10 - Удерейское, 11 - Васильевское, 12 - Герфед, 13 - Попутнинское, 14 - Богунайское, 15 - Кузеевское 
положить переотложение кластогенного и хемогенно-диагенетического (первично-осадочного) золота гидротермальными растворами в тепловых полях магматических или метаморфических тел, проявляющихся в то или иное геологическое время. Неоднозначность интерпретации геологических и аналитических результатов вносит сложности в получение надежной аргументации генетических выводов. Причем абсолютные датировки геологических процессов оцениваются по косвенным признакам, изотопным отношениям в минералах, которые часто являются непарагенетическими датируемым процессам. Нами проведена геохронологическая интерпретация гранитообразования, метаморфизма и золоторудного процесса на крупном золото-сульфидно-вкрапленном месторождении «Панимба» по цирконам и мусковитам с характеристикой методов исследования материала и аналитических результатов.

Получение новой, геологически обоснованной, аналитической информации хорошо изученных месторождений способствует развитию общей теории рудообразования. Достижением последнего времени является разработка и использование Re-Os-метода геохронологического датирования золоторудного процесса по арсенопириту - минералу, образующемуся совместно с золотом в рудах Енисейского кряжа [15]. Весьма привлекательна идея Ю.А. Шуколюкова с соавторами [14] о возможности изотопного датирования самородного золота U-Th-Не-методом. Разработка метода может снять многие проблемные вопросы абсолютной геохронологии месторождений золота.

\section{Методы исследований}

Нами выполнены определения абсолютного возраста цирконов из гранита, графитсодержащего и сульфидизированного сланца рудного тела и мусковита из жильного кварца месторождения руч. Золотого. В исследовании использовались следующие методы:

1. U-Pb-геохронология цирконов, выделенных из гранита, проводилась с помощью мультиколлекторного вторично-ионного высокоразрешающего масс-спектрометра SHRIMP II (в ЦИИ ВСЕГЕИ, аналитик А.Н. Ларионов) по методике, описанной ранее [16], а циркона из сланца с помощью изотопного мультиколлекторного плазменного масс-спектрометра Thermo Quest Finnigann MAT NEPTUNE и системы лазерной абляции DUV-193, оснащенной эксимерным лазером СОМРЕХ-102 (в ЦИИ ВСЕГЕИ, аналитик И.Н. Капитонов) по методике [9]. Выделение циркона из гранита и сланца осуществлялось по стандартной методике [6]. Монтаж зерен в шайбы и дальнейшая технология пробоподготовки описаны ранее [9]. Обработка аналитических данных осуществлялась в программе ISOPLOT/E x 3.22.

2. Ar-Ar-геохронология выполнена в Аналитическом центре многоэлементных и изотопных исследований ИГМ СО РАН, г. Новосибирск (аналитик А.В. Травин), методом ступенчатого прогрева по минеральным фракциям мусковита [12].

Особенности минерального и химического состава образцов гранита и графитсодержащего сланца исследованы методами: люминесцентно-битуминологическим (в лаборатории НИТПУ, г. Томск, на кафедре ГиРПИ, аналитик М.И. Шаминова); рентгенофлуоресцентным (на энергодисперсионном рентгенофлуоресцентном анализаторе ED 2000 (Oxford) в ЦКП «Аналитический центр геохимии природных систем» НИТГУ, г. Томск, аналитик Е.М. Асочакова). РТХ - условия образования мусковитсодержащего жильного кварца оценены методами термокриометрии и КР-спектроскопии в ИГМ СО РАН [10]. 


\section{Общая характеристика геологического положения}

и состава исследованных образцов

Рудное поле месторождения «Панимба» объединяет участки руч. Золотого, Михайловское и проявлений Тавлик, Правобережное. Рудные зоны расположены в юго-западном крыле Центрального антиклинория Енисейского кряжа в 1,5-2 км от выходов гранитов на юге Чиримбинского интрузива. Рудные тела месторождения представлены метапелитовыми углеродсодержащими сланцами, инъецированными жилами, линзами и прожилками кварца. Сланцы и жильный кварц импрегнированы арсенопиритом, пирротином и пиритом. В меньшей мере распространены галенит, сфалерит и халькопирит. Руды относятся к золотокварцевому малосульфидному типу. В 2015 г. на участках Михайловском и руч. Золотого завершены геологоразведочные работы с подсчетом запасов, месторождение является первоочередным объектом для организации эксплуатационных работ.

Материал для исследований отобран из керна геолого-разведочных скважин РЛ-9 участка руч. Золотого (рис. 2) и ближайших выходов гранита. В строении разреза принимают участие андалузитовые двуслюдяные сланцы, образованные по ритмичнополосчатым отложениям песчано-алевритово-глинистой толщи кординской свиты нижнего рифея. Минерализованная зона с рудными телами вскрыта в нижележащих узловатых кордиерит-андалузитовых двуслюдяных углеродизированных сланцах тонкослоистой алеврито-глинистой толщи, милонитизированных в сечении субширотного чешуйчатого сброса.

Образец ГрПнб-1. Умеренно-щелочной гранит. Отобран в 100 м от контакта интрузии, на широте месторождения руч. Золотого. Минеральный состав, в \%: хлоритизированный биотит - 3; олигоклаз - 10-15; микроклин - 40-45; кварц - 25-30; циркон, апатит, сфен - до 3. Химический состав, в мас. \%: $\mathrm{SiO}_{2}-73,55 ; \mathrm{TiO}_{2}-0,19 ; \mathrm{Al}_{2} \mathrm{O}_{3}-15,51 ; \mathrm{Fe}_{2} \mathrm{O}_{3}$ общ. $-2,47 ; \mathrm{MnO}-0,03$; $\mathrm{MgO}-0,36 ; \mathrm{CaO}-0,69 ; \mathrm{Na}_{2} \mathrm{O}-2,64 ; \mathrm{K}_{2} \mathrm{O}-3,38 ; \mathrm{P}_{2} \mathrm{O}_{5}-0,06$; п.п.п. $-0,82$. В нитевидных трещинах выявлены смолисто-маслянистые битумоиды.

Образеи 146/200-210. Черный графитсодержащий хлорит-серицитовый сульфидизированный сланец рудного интервала. Содержание золота 9,0 г/т. Сульфиды - зернистая вкрапленность пирита, пирротина, халькопирита, галенита. В ореоле зерен сульфидов распространены смолисто-маслянистые битумоиды. Акцессорные минералы - турмалин, рутил, циркон. Химический состав, в мас. \%: $\mathrm{SiO}_{2}-50,68 ; \mathrm{TiO}_{2}-0,76 ; \mathrm{Al}_{2} \mathrm{O}_{3}-30,46 ; \mathrm{Fe}_{2} \mathrm{O}_{3}$ общ. $-5,43 ; \mathrm{MnO}-0,03$; $\mathrm{MgO}-2,01 ; \mathrm{CaO}-0,27 ; \mathrm{Na}_{2} \mathrm{O}-0,07 ; \mathrm{K}_{2} \mathrm{O}-4,33 ; \mathrm{P}_{2} \mathrm{O}_{5}-0,04 ;$ п.п.п. $-5,22$.

Образеи 191/337,8. Жильный кварц с вкрапленностью пирита, пирротина, арсенопирита и чешуек мусковита в зеленовато-сером узловатом пятнистом сланце. Рудный интервал, содержание золота - 15,1 г/т. Кварц серый мелкозернистый. РТХ-параметры образования жильного кварца косвенно оценены методами термобарогеохимии флюидных включений. Состав включений: 1) существенно водные - Ж $\left(\mathrm{H}_{2} \mathrm{O}\right)+\Gamma$; 2) водно-углекислотные Ж $\left(\mathrm{H}_{2} \mathrm{O}+\mathrm{CO}_{2}\right)$, Ж $\left(\mathrm{H}_{2} \mathrm{O}\right)+\Gamma\left(\mathrm{CO}_{2}\right)$ и Ж $\left.\left(\mathrm{H}_{2} \mathrm{O}\right)+Ж\left(\mathrm{CO}_{2} \pm \mathrm{CH}_{4} \pm \mathrm{N}_{2}\right) ; 3\right)$ кристаллофлюидные включения Ж $\left.\left(\mathrm{H}_{2} \mathrm{O}\right)+\Gamma+\mathrm{KP} ; 4\right)$ однофазные газовые включения, заполненные смесью газов углекислоты, метана и азота $\Gamma\left(\mathrm{CO}_{2}+\mathrm{CH}_{4}+\mathrm{N}_{2}\right)$, и однофазные включения жидкой углекислоты. Температура общей гомогенизации первичных флюидных включений составляет интервал от 165 до $300^{\circ} \mathrm{C}$. В зависимости от плотностей содержимого включений гомоге- 


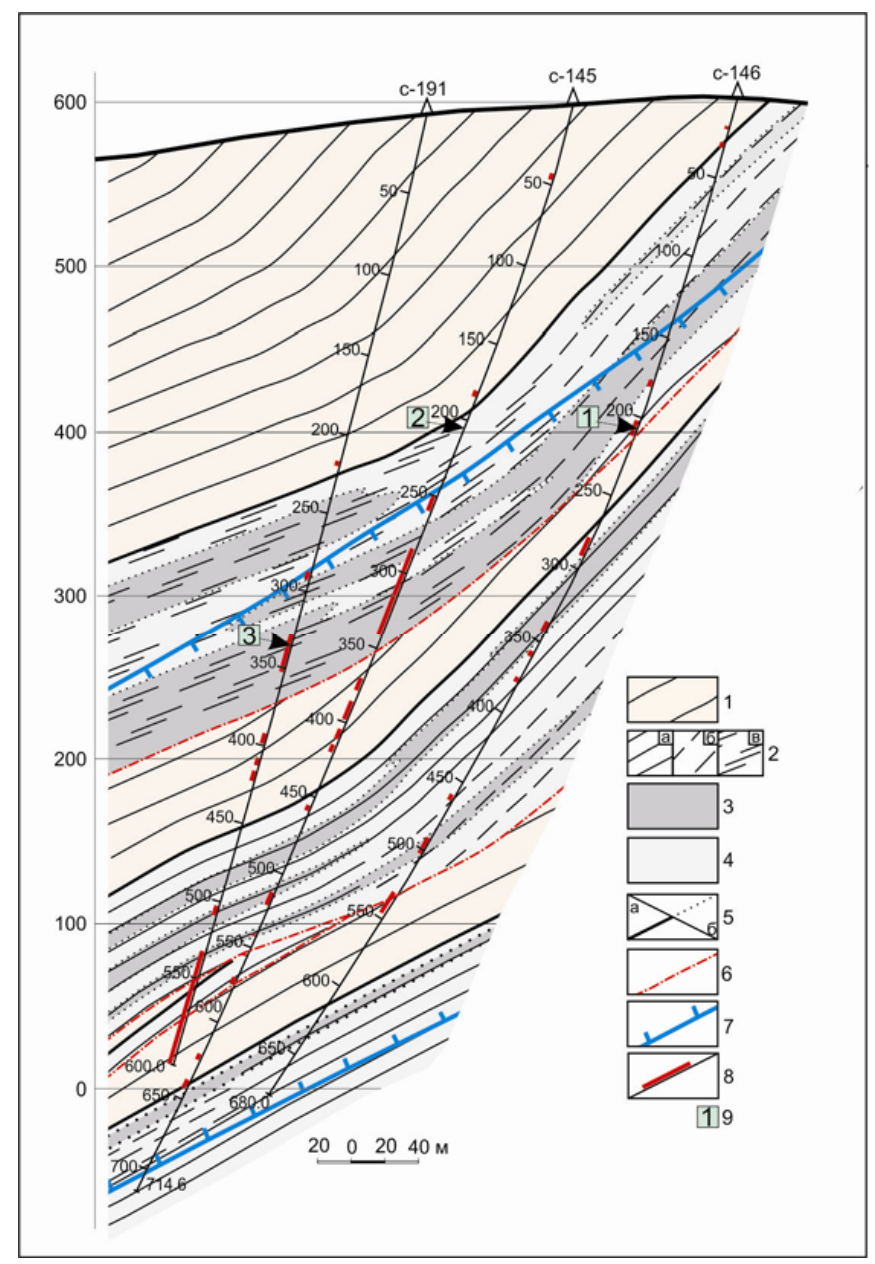

Рис. 2. Геологический разрез участка руч. Золотого, РЛ - 9 (составил А.М. Сазонов): 1 - светло-бежевосерые с ритмичной реликтовой песчано-алеврито-глинистой слоистостью; 2 - 4 - зеленовато-серые углеродистые метапелитовые сланцы: 2 - текстуры сланцев: а - реликтовая тонкая слоистость, б - в милонитовая полосчатость: б - неясная тонкая, в - тонко- и нитевидно-штриховатая; 3 - зеленовато-серые узловатые двуслюдяные бластомилониты; 4 - зеленовато-серые кордиерит-андалузитовые двуслюдяные бластомилониты; 5 - границы: а - литологические, б - метаморфических тел; 6 - дизьюнктивы; 7 границы минерализованной золотоносной зоны; 8 - интервалы гидротермально-измененных пород с содержанием золота более 0,5 г/т; 9 - участки отбора проб на абсолютный возраст: 1 - обр.146/200210. Циркон из сульфидизированного сланца; 2 - обр. 145/218. Мусковит из безрудного кварца; 3 - обр. 191/337,8. Мусковит из рудного кварца

низация происходила в жидкую или газовую фазы. Давление флюида в индивидуальных газовых включениях золотоносного кварца от 0,6 до 2,9 кбар при температурах от 165 до $300{ }^{\circ} \mathrm{C}[11]$.

Образец 145/218. Жильный кварц с вкрапленностью пирита и единичных чешуек мусковита. Кварц мелкозернистый, темно-серый за счет крапа микрозерен графита и антраксолита. Содержание золота в интервале 0,1 г/т. Вмещающие сланцы светло-пепельно-зеленовато-серые пятнистые с вкрапленностью пирротина.

В кварце присутствуют однофазные и двухфазные включения. Соотношение жидкости $\left(\mathrm{H}_{2} \mathrm{O}\right)$ и газа во включениях изменяется от 90:10 и 10:90. Газовая фаза представлена метаном 
или смесью (мольные, \%) - $\mathrm{CO}_{2} 26-55 ; \mathrm{CH}_{4} 44-100 ; \mathrm{N}_{2}$ 13. Однофазные газовые включения метан-углекислотные, азот-метан-углекислотные, метановые. Температура общей гомогенизации (в жидкость) первичных двухфазных включений от 117,4 до $213^{\circ} \mathrm{C}$. Температура плавления (минус) $1-2{ }^{\circ} \mathrm{C}$ и температура эвтектики (минус) $24-40^{\circ} \mathrm{C}$. Первичные однофазные включения в безрудном кварце имеют температуру частичной гомогенизации (минус) $11,5-83{ }^{\circ} \mathrm{C}$ и температуру плавления (минус) $62-95^{\circ} \mathrm{C}$.

\section{Результаты и обсуждение исследований}

Цирконы в изученных пробах гранита и сланца имеют разнообразную окраску, преимущественно идиоморфную морфологию, зональное строение и реже овальную форму (рис. 3). Результаты показывают широкий интервал возрастов цирконов гранитоидов, минерализованного сланца и мусковитов из жильного кварца (рис. 4,5$)$.

\section{Цирконы гранита}

Цирконы из пробы гранита коричневого цвета, полупрозрачные и мутные с пленками гидроксидов железа, представлены идиоморфными трещиноватыми кристаллами призматического габитуса и их обломками. Длина кристаллов от 200 до 350 мкм. Коэффициент удлинения от 2 до 3. В катодно-люминесцентном свете цирконы имеют слабое свечение, выявляется двухфазное строение: светлая центральная часть с магматической зональностью и темная краевая со следами зональности.

По результатам U-Pb-датирования для цирконов получен конкордантный возраст $(868,9 \pm 6,5)$ млн лет. $\mathrm{U}=355-2491, \mathrm{Th}=168-709, \mathrm{Th} / \mathrm{U}=0,29-0,63$ (табл. 1, рис. 3$)$.

\section{Цирконы минерализованного сланца}

В пробе графитсодержащего хлорит-серицитового сульфидизированного сланца из рудного интервала обнаружены цирконы светло-розовые, бесцветные, коричневатые, прозрачные, полупрозрачные и мутные, идиоморфные (реже субидиоморфные) призматические кристаллы и их обломки, реже встречаются овальные зерна. Во многих зернах наблюдаются темные включения и/или трещинки. Длина кристаллов составляет от 67 до 222 мкм. Коэффициент удлинения 1,0-3,2. По результатам датирования 52 зерен получен широкий спектр возрастов (рис. 3 и 4 ).

Палеозой. Первая группа - 5 зерен. Цирконы № 6, 51, 24, 45 и 27 прозрачные и полупрозрачные (24 и 27), большинство с включениями и/или трещинками, идиоморфный призматический кристалл (51), обломки неправильной формы $(6,24)$, кристалл (45) и обломок субидиоморфного призматического кристалла (27). В катодных лучах цирконы имеют яркое свечение, a 45 - серое, незональное, с тонкой (51 и 27) и следами грубой (24) зональности. Для них получен возраст в интервале от $(250,4 \pm 23,0)$ до $(288,3 \pm 15,7)$ млн лет - табличные значения по $206 \mathrm{~Pb} / 238 \mathrm{U}$. Th/U=0,75-1,67.

Вторая группа - 4 зерна. Цирконы № 13, 29, 12 и 33 имеют возраст в интервале от $(316,1 \pm 11,6)$ до $(342,5 \pm 15,7)$ млн лет - табличные значения по $206 \mathrm{~Pb} / 238 \mathrm{U}$. Th/U=0,38-1,05. Цирконы прозрачные (12 и 33) и полупрозрачные (13 и 29). В основном они представлены субидиоморфными призматическими кристаллами или их обломками с включениями, а 13 - окатанное зерно. В 


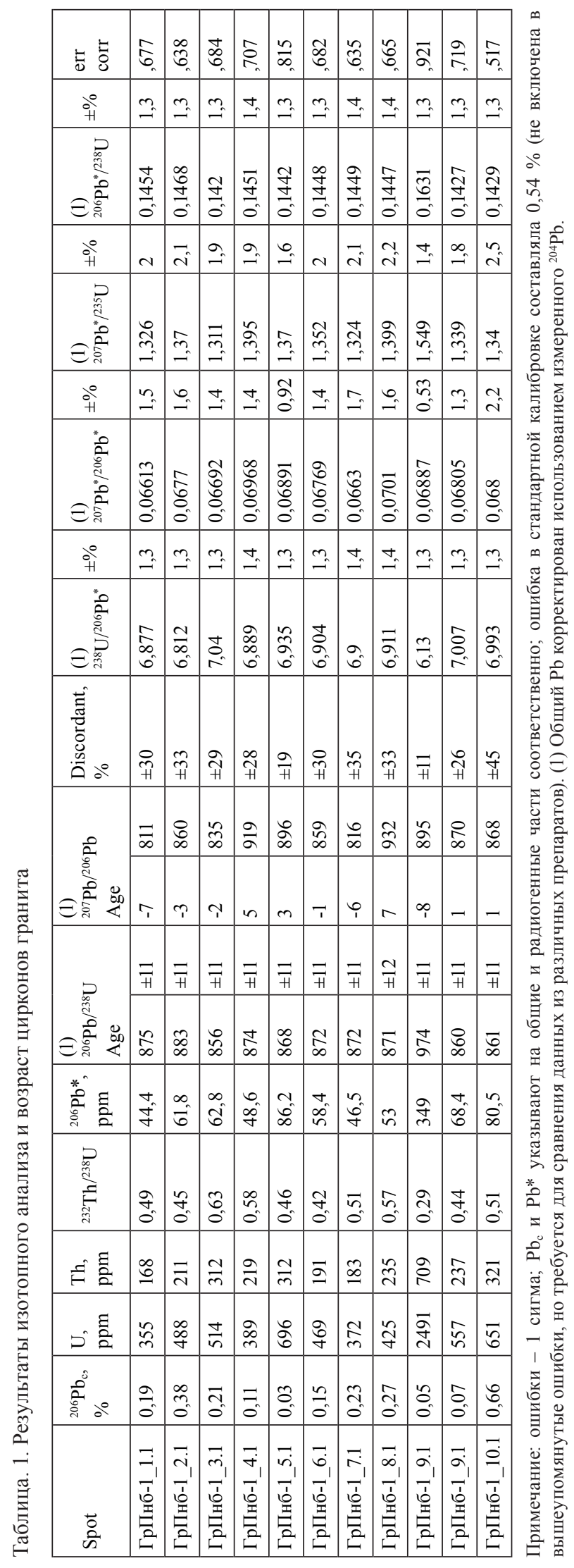




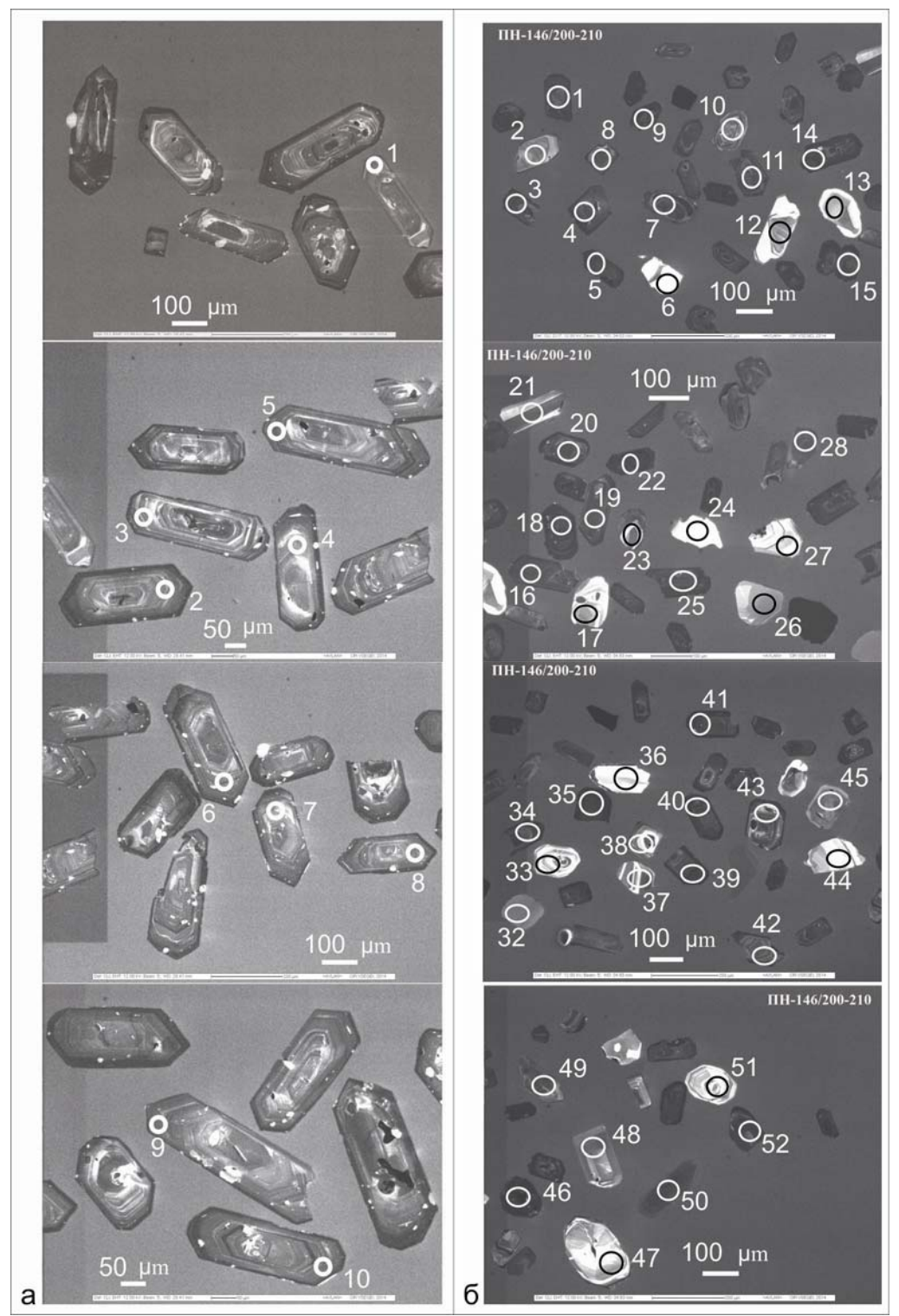

Рис. 3. Внутреннее строение циркона в катодных лучах с точками U-Pb-датирования: а - образец ГрПнб-1 (гранит); б - образец 146/200-210 (сланец)

катодных лучах имеют яркое свечение, кроме 29 - слабое свечение. Цирконы 12 и 33 имеют тонкую зональность или ее следы, 29 - следы грубой зональности с тонкой темной каемкой.

Третья группа - 2 зерна. Цирконы № 48 и 32 прозрачные и полупрозрачные соответственно: 48 - с включениями, идиоморфный призматический обломок кристалла, а 32 - неправильной формы окатанное зерно. В катодных лучах оба имеют умеренное свечение, 32 - серое, незональное, а 48 - со следами тонкой зональности. Для них получен возраст в интервале от $(370,7 \pm 19,3)$ до $(394,6 \pm 12,4)$ млн лет - табличные значения по $206 \mathrm{~Pb} / 238 \mathrm{U}$. Th/U=0,58-1,21.

Четвертая группа - 2 зерна. Цирконы 31 и 38 мутны и прозрачны соответственно: 38 субидиоморфный призматический обломок кристалла, а 31 - неправильной формы обломок. В 

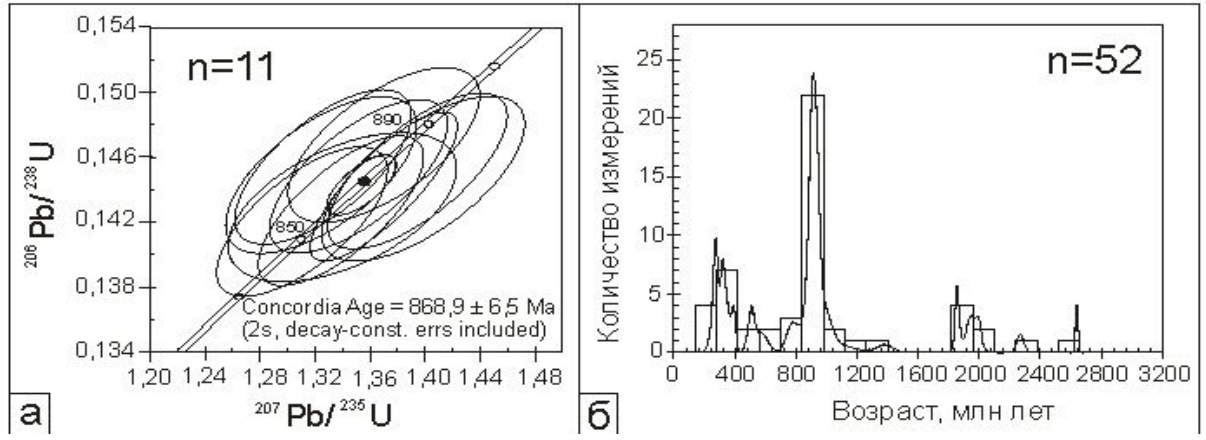

Рис. 4. Графики изотопно-геохронологических анализов: а - положение точек составов цирконов из образца гранита (ГрПнб-1) на диаграмме с конкордией. Конкордантный возраст $(868,9 \pm 6,5)$, млн лет $(2 \sigma$,

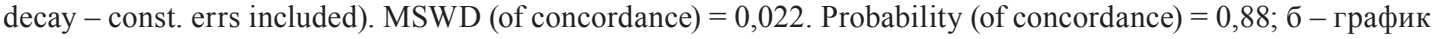
возрастной вероятности U-Pb-датировки цирконов образца минерализованного сланца (146/200-210). Возрастной спектр, млн лет: 250,4 $23,0-2639,9 \pm 8,7$

катодных лучах 38 имеет умеренное свечение и тонкую зональность, а 31 - черный, незональный. Для них получен возраст в интервале от $(499,5 \pm 25,1)$ до $(511,4 \pm 16,8)$ млн лет - табличные значения по $206 \mathrm{~Pb} / 238 \mathrm{U}$. Th/U=0,37 (38) и 4,44(31).

Геологические события палеозойского возраста (между кембрием и девоном, девоном и карбоном, карбоном и юрой) характеризовались вспышками вулканизма [3]. Нами ранее был установлен позднетриасовый возраст вулканитов Севернинского палеовулкана в ЮжноЕнисейском кряже (222-225 млн лет, K-Ar-метод по валовым пробам гранит-порфиров, риолитов, умеренно-щелочных долеритов); позднедевонский - флюорит-кальцитовых прожилков с пирротин-халькопирит-сфалерит-галенитовой минерализацией в рудах месторождения «Благодатное» - 368-364 млн лет, Rb-Sr и Sm-Nd-методы по пробам флюорита, мусковита $[8,11]$; среднеордовикский - гранитов Белогорского и Нижнеканского массивов в ЮжноЕнисейском кряже - 466-467 млн лет, Ar-Ar-метод по мусковиту и U-Pb-метод по циркону и сфену.

Beнd. Пятая группа - 2 зерна. Цирконы № 21 и 10 полупрозрачные, 10 - субидиоморфный призматический обломок кристалла, а 21 - неправильной формы окатанный обломок. В катодных лучах оба имеют умеренное свечение, 21 с грубой, а 10 с тонкой зональностью. Для них получен возраст в интервале от $(567,7 \pm 36,6)$ до $(580,6 \pm 49,1)$ млн лет - табличные значения по $206 \mathrm{~Pb} / 238 \mathrm{U} . \mathrm{Th} / \mathrm{U}=1,06-1,07$.

Во вмещающих сланцах золоторудных месторождений Александро-Агеевского, Перевальнинского и Верхне-Енашиминского рудных полей отмечается нитевидное калишпатовое прожилкование. В прожилках развиты пирит, гематит, турмалин, сфен и хлорит. Несмотря на обычно микроскопические размеры прожилков, вмещающие сланцы интенсивно диафторированы. Ar-Ar-возраст калишпатовой минерализации из рудного кварца месторождения «Эльдорадо», млн лет: плато - 549,8 4 ,6; интегральный $-571,5 \pm 4,8$.

Поздний рифей. Шестая группа - 3 зерна. Цирконы № 50, 36 и 37 прозрачные (36) и полупрозрачные, с включениями или трещинками, субидиоморфный призматический обломок кристалла (36) и округлой и овальной формы зерна (37 и 50). В катодных лучах имеют слабое 


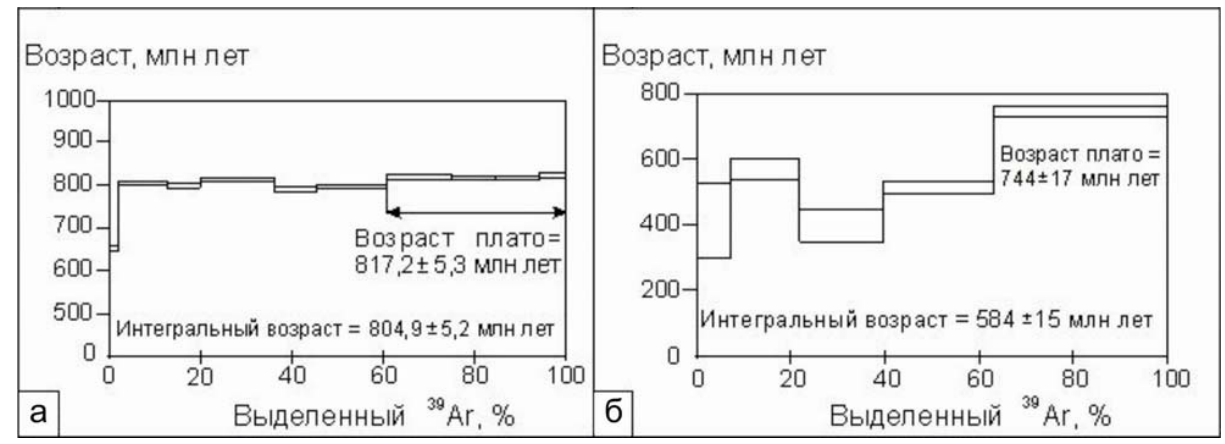

Рис. 5 Возрастной спектр мусковитов из жильного кварца: а - образец 191/337,8, в млн лет: по методу плато $817,2 \pm 5,3$; интегральный возраст $804,9 \pm 5,2$; б - образец 145/218, в млн лет: по методу плато $744 \pm 17$, интегральный возраст $584 \pm 15$

(черное, незональное - 50) и яркое свечение (36 и 37), наблюдаются следы грубой зональности. Для них получен возраст в интервале от $(762,3 \pm 33,3)$ до $(815,0 \pm 37,6)$ млн лет - табличные значения по 206 Pb/238U. Th/U=0,02(50) и 0,89-1,03.

Седьмая группа - 19 зерен. Цирконы полупрозрачные, прозрачные $(16,39,19,1,8,3)$ и мутные $(9,15,22,18,23)$, идиоморфные призматические кристаллы или их обломки (большинство), а также субидиоморфное (15) и окатанное зерно (23). Практически все с включениями и/или трещинками. В катодных лучах цирконы как со слабым свечением до черных без видимой зональности, так и с умеренным $(43,49,23,8)$ свечением, с грубой зональностью или ее следами, а 43, 42 и 11 с тонкой зональностью или ее следами. Возраст - от $(889,0 \pm 26,6)$ до $(996,0 \pm 32,9)$ млн лет - табличные значения по ${ }^{206} \mathrm{~Pb} /{ }^{238} \mathrm{U}$. Th/U=0,48-1,50.

В позднем рифее в Заангарье Енисейского кряжа сформировались гранитоиды Тейского комплекса (1000-950 млн лет), Ерудинского (880 млн лет) и Каламинского (880-775 млн лет) массивов. Метаморфические сланцы рудных полей Восточного золотоносного пояса Енисейского кряжа имеют возраст 800-775 млн лет, а золото-арсенопиритовая, золото-полиметаллическая и сурьмяная рудные ассоциации месторождений золота - 750-650 млн лет [8, 11, 15].

Средний рифей. Восьмая группа - 1 зерно. Циркон представлен полупрозрачным с трещинками обломком идиоморфного призматического кристалла со слабым свечением в катод-

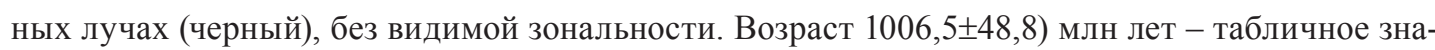
чение по ${ }^{207} \mathrm{~Pb} /{ }^{206} \mathrm{~Pb}$. Th/ $\mathrm{U}=0,63$.

Девятая группа - 1 зерно. Циркон представлен полупрозрачным с включениями и трещинками идиоморфным призматическим кристаллом со слабым свечением в катодных лучах (черный). Возраст $(1132,7 \pm 79,1)$ млн лет - табличное значение по ${ }^{207} \mathrm{~Pb} /{ }^{206} \mathrm{~Pb}$. Th/U=1,05.

Десятая группа - 1 зерно. Циркон представлен мутным идиоморфным призматическим кристаллом со слабым свечением в катодных лучах, без видимой зональности. Возраст $(1308,9 \pm 52,3)$ млн лет - табличное значение по ${ }^{207} \mathrm{~Pb} /{ }^{206} \mathrm{~Pb}$. Th/U=0,79.

Среднерифейская эра развития Енисейского кряжа характеризовалась региональным метаморфизмом отложений сухопитской серии - 1350-1000 млн лет $[8,11]$.

Ранний протерозой. Одиннадцатая группа - 2 зерна. Циркон представлен мутным идиоморфным призматическим кристаллом со слабым свечением в катодных лучах, без види- 
мой зональности. Возраст от $(1852,9 \pm 10,4)$ до $(1861,3 \pm 16,6)$ млн лет - табличные значения по ${ }^{207} \mathrm{~Pb} /{ }^{206} \mathrm{~Pb} . \mathrm{Th} / \mathrm{U}=0,40-0,50$.

Двенадцатая группа - 4 зерна. Цирконы № 7 и 46 мутные; 17 - прозрачное, а 26 - полупрозрачное окатанные зерна (обломки). В цирконе 17 наблюдаются включения. В катодных лучах 17 и 26 имеют яркое, а 7 и 46 - слабое свечение, (46 - черный незональный). Зерна 7 и 17 со следами тонкой зональности, а в 26 наблюдается секториальная зональность. Возраст от $(1931,6 \pm 59,6)$ до $(1996,8 \pm 18,1)$ млн лет - табличные значения по ${ }^{207} \mathrm{~Pb} /{ }^{206} \mathrm{~Pb}$. Th/U=0,60-1,12.

Тринадцатая группа - 1 зерно. Циркон представлен прозрачным обломком неправильной формы. В катодных лучах имеет яркое свечение и секториальную зональность. Возраст $(2269,6 \pm 23,1)$ млн лет - табличное значение по ${ }^{207} \mathrm{~Pb} /{ }^{206} \mathrm{~Pb}$. Th/ $\mathrm{U}=0,21$.

По нашим исследованиям и более ранним представлениям Ю.А. Кузнецова, А.Д. Ножкина, О.М. Туркиной $[3,13]$, в раннем протерозое происходила интенсивная мигматизация (при температурах амфиболитовой фации метаморфизма) гранулитов и гнейсов кузеевской и атамановской толщ архея, формировался амфиболитовый енисейский метаморфический комплекс Южно-Енисейского кряжа и внедрились таракские граниты.

Поздний архей. Четырнадцатая группа - 1 зерно. Это прозрачное с включениями овальной формы окатанное трещиноватое зерно, с ярким свечением в катодных лучах, секториальной зональностью и серой метаморфической каемочкой. Возраст - $(2639,9 \pm 8,7)$ млн лет табличное значение по ${ }^{207} \mathrm{~Pb} /{ }^{206} \mathrm{~Pb}$. Th/U=0,67.

В позднем архее завершилось формирование канского метаморфического комплекса гранулитов и чарнокитов и проявился вулканизм, образовавший осадочно-вулканогенные толщи енисейской серии [3].

\section{Мусковит из гидротермального квариа}

Возраст мусковитов из жильного кварца: образец 191/337,8, в млн лет - по методу плато $817,2 \pm 5,3$, интегральный возраст $804,9 \pm 5,2$; образец $145 / 218$, в млн лет - по методу плато $744 \pm 17$, интегральный возраст $584 \pm 15$.

При интерпретации Ar-Ar-результатов датировок мусковита следует учитывать, что Ar$\mathrm{Ar}$-система в минерале открывается при температуре $325-375^{\circ} \mathrm{C}$ [17]. Термобарогеохимические исследования газово-жидких включений в кварце показывают, что кварц, содержащий мусковит, образовался при температуре ниже $300{ }^{\circ} \mathrm{C}$ и не подвергался высокотемпературному воздействию после кристаллизации ассоциации кварц+мусковит. Это указывает на приемлемую достоверность полученных результатов.

\section{Выводы}

Изотопно-геохронологические исследования позволяют сделать следующие выводы:

В акцессорном цирконе метапелита кординской свиты, вмещающем рудные тела месторождения, отразилась длительная тектономагматическая история развития Енисейского кряжа от верхнеархейского до верхнепалеозойского возраста.

Цирконы верхнеархейского и раннепротерозойского возрастов представляют собой кластогенные зерна продуктов сноса из области выветривания мигматизированных гранулитов канского метаморфического комплекса (2639,9 и 1852,9-2269,6 млн лет). 
Наибольшим распространением в сланце пользуются цирконы с возрастом 1132,7762,3 млн лет, отвечающие гренвилльским событиям в развитии Енисейского кряжа. На начальной стадии гренвилльской орогении отложения сухопитской серии, испытавшие складчатость, региональный метаморфизм от зеленосланцевой до амфиболитовой фаций, прорваны интрузиями гнейсо-гранитов тейского комплекса. В позднегренвилльское время в золотоносном поясе Енисейского кряжа проявились гранитообразование татарско-аяхтинского комплекса, контактово-термальный и динамометаморфизм в зонах Ишимбинского и Татарского разломов.

Метаморфизм сланцев тектонической зоны Панимбинского месторождения характеризуется интервалом $(996,0 \pm 32,9)$ - $(889,0 \pm 26,6)$ млн лет. Возраст гранитов Чиримбинского массива татарско-аяхтинского комплекса, обнажающихся на западном фланге рудного поля, $(868,9 \pm 6,5)$ млн лет. Возраст гидротермального кварцево-жильного минералообразования с золотосульфидной минерализацией оценивается интервалом $(817,2 \pm 5,3)-(744 \pm 17)$ млн лет (по мусковиту из жильного кварца) и $(815,0 \pm 37,6)$ - $(762,3 \pm 33,3)$ млн лет (по циркону из рудного сланца).

Изотопные датировки цирконов из сланца 580,6-567,7; 511,4-499, 5 и 394,6-370,7 млн лет соответствуют возрастам байкальской, салаирской и каледонской эпохам диастрофизма в складчатом обрамлении Сибирской платформы. В вендское и верхнедевонское время в месторождениях Восточного золотоносного пояса проявилась обильная тонкопрожилковая калишпатовая и кварц-карбонатная минерализация, часто с сульфидной вкрапленностью.

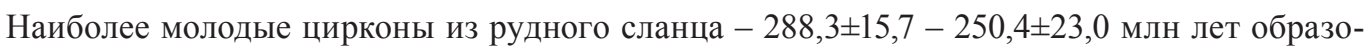
вались в процессе пермско-триасовой тектономагматической активизации стабилизированной складчатой области Енисейского кряжа. Согласно легенде Енисейской серии государственной геологической карты Российской Федерации масштаба 1:200 000 [4], этому времени соответствуют проявления ведугинского комплекса даек долеритов и ийолит-сиенитовового кийского комплекса. Ранее свидетельств проявления образований этого возраста в рудных полях Восточного золотоносного пояса не отмечалось.

Работа выполнена при финансовой поддержке Фонда Михаила Прохорова (договор № AM-22/14 от 1.04.2014) и КГАУ «Красноярский краевой фонд поддержкки научной и научнотехнической деятельности» (Дополнительное соглачение № 21/14 от 24.09.2014). Авторы выражают признательность В.Ф. Проскурнину, О.В. Вакуленко (ВСЕГЕИ), А.А. Томиленко, А.В. Травину (ИГМ СО РАН), М.И. Шаминовой (НИТПУ, г. Томск), Н.В. Гафуровой (СФУ) за помощь в проведении аналитических исследований и обсуждение результатов.

\section{Список литературы}

[1] Бернштейн П.С. Условия локализации различных типов золоторудных месторождений Енисейского кряжа. Труды ЦНИГРИ, 1962, 43, 47-55 [Bershtein P.S. Conditions of localization of various types of gold deposits of the Yenisei ridge. The proceedings of TsNIGRI, 1962, 43, 47-55 (in Russian)]

[2] Буряк В.А., Бакулин Ю.И. Металлогения золота. Владивосток: Дальнаука, 1998, 403 с. [Buriak V.A., Bakulin Iu.I. Metallogeny of gold. Vladivostok, Dalnauka, 1998, 403 p. (in Russian)] 
[3] Кузнецов Ю.А. Петрология докембрия Южно-Енисейского кряжа. Новосибирск, 1988, 221 c. [Kuznetsov Iu.A. Petrology of the Precambrian of the South Yenisei ridge. Novosibirsk, 1988, 221 p. (in Russian)]

[4] Легенда Енисейской серии государственной геологической карты Российской Федеращии. Изд. 2-е. Масштаб 1:200000. Министерство природных ресурсов РФ, ФГУГП «Красноярскгеолсъемка». Красноярск, 2002. [Legend of the Yenisei series of the state geological map of Russian Federation, Issue 2, Krasnoyarsk, 2002 (in Russian)]

[5] Ли Л.В., Шохина О.И. Геохимия золота в метаморфических и магматических сериях докембрия (на примере Енисейского кряжа). М.: Недра, 1985, 133 с. [Li L.V., Shokhina O.I. Geochemistry of gold in magmatic and metamorphic series of the Precambrian (on the example of the Yenisei ridge). Moscow, Nedra, 1985, 133 p. (in Russian)]

[6] Ляхович В.В. Рациональная методика извлечения акиессорных минералов из гранитоидов. М., Недра, 1966, 48 с. [Liakhovich V.V. A rational methodology for extraction of the accessory minerals of granitoids ). Moscow, Nedra, 1966, 48 p. (in Russian)]

[7] Петров В.Г. Золото в опорных разрезах верхнего докембрия западной окраины Сuбирской платформы. Новосибирск: Наука, Сиб. отд., 1976, вып. 320, 213 с. [Petrov V.G. Gold in the reference sections of upper Precambrian of the Western margin of the Siberian platform. Novosibirsk, Nauka, 1976, 320, 213 c. (in Russian)]

[8] Полева Т.В., Сазонов А.М. Геология золоторудного месторождения Благодатное в Енисейском кряже, Ин-т исслед. товародвижения и конъюнктуры оптового рынка (ОАО «Иткор»). М., 2012, 290 c. [Poleva T.V., Sazonov A.M. Geology of gold ore deposits of grace in the Yenisei ridge. Moscow, 2012, 290 p. (in Russian)]

[9] Капитонов И.Н., Петров О.В., Шевченко С.С. и др. Изотопно-геохимические и геохронологические исследования цирконов пелагических илов из района арктических хребтов Ломоносова и Альфа-Менделеева. Региональная геология и металлогения, 2014, 60, 5-20 [Kapitonov I.N., Petrov O.V., Shevchenko S.S. et. al. Isotope-geochemical and geochronological studies of zircons from pelagic silts from the area of the Arctic ridges Lomonosov and alphaMendeleev. Regional Geology and metallogeny, 2014, 60, 5-20 (in Russian)]

[10] Рябуха М.А. Условия формирования золотоносных и незолотоносных кварцевых жил участка Михайловского (месторождение «Панимба», Енисейский кряж) , $X V$ Всероссийская конференщия по термобарогеохимии (Москва, ИГЕМ РАН, 18-20 сентября 2012 г.) М.: ИГЕМ РАН, 2012, с. 70-71 [Riabukha M.A. The conditions of formation of gold-bearing quartz veins and resolutiony section of Mikhailovsky Deposit (Panimba, Yenisei ridge). XV All-Russian conference on thermobarogeochemistry. Moscow, 2012, p. 70-71 (in Russian)]

[11] Сазонов А.М., Ананьев А.А., Полева Т.В. и др. Золоторудная металлогения Енисейского кряжа: геолого-структурная позиция, структурные типы рудных полей. Журнал СФУ. Техника и технологии, 2010, 4, (3), 371-395 [Sazonov A.M., Ananiev A.A., Poleva T.V. et. al. Gold metallogeny of the Yenisei ridge: geological-structural position structural types of ore fields. J. Sib. Fed. Univ. Eng. technol., 2010, 4, (3), 371-395 (in Russian)]

[12] Травин А.В., Юдин Д.С., Владимиров А.Г. и др. Термохронология Чернорудской гранулитовой зоны (Ольхонский регион, Западное Прибайкалье). Геохимия, 2009 , 11, 1181-1199

$$
-187 \text { - }
$$


[Travin A.V., Iudin D.S., Vladimirov A.G. et.al. Thermochronology Chernorudskiy granulite zone (the ol'khon region, Western Baikal area). Geokhimiya, 2009 , 11, 1181-1199 (in Russian)]

[13] Туркина О.М., Ножкин А.Д., Баянова Т.Б. и др. Докембрийские террейны югозападного обрамления Сибирского кратона: изотопные провинции, этапы формирования коры и аккреционно-коллизионных событий. Геология и геофизика, 2007, 48 (1), 80 -92 [Turkina O.M., Nozhkin A.D., Baianova T.B. et.al. Precambrian terranes in the southwestern framing of the Siberian craton: isotopic provinces, stages of crustal accretion and collision events. Gejljgiia I Geofizika, 2007, 48 (1), 80-92 (in Russian)]

[14] Шуколюков Ю.А., Якубович О.В., Рыцк Ю.А. О возможности изотопного датирования самородного золота U-Th-Не -методом. ДАН, 2010, 430(2), 243-247 [Shukolukov Iu., A., Iakubovich O.V., Rytsk Iu.A. About possibility of isotope Dating of native gold U-Th-He method. Reports of RAS, 2010, 430(2), 243-247 (in Russian)]

[15] Borisenko A.S., Sazonov A.M., Nevolko P.A., Naumov E.A., Tessalina S., Kovalev K.R., Sukhorukov V.P. Gold Deposits of the Yenisei Ridge (Russia) and Age of Its Formation. Acta Geologica Sinica (English Edition), 88 (supp. 2), 2014, 686-687.

[16] Larionov A.N., Andreichev V.A., Gee D.G. The Vendian alkaline igneous suite of northern Timan: ion microprobe $\mathrm{U} / \mathrm{Pb}$ zircon ages of gabbros and syenite. Geological Society, London, Memoirs, 2004, 30(1), 69-74.

[17] Spear Frank S. Metamorphic Phase Equilibria And Presure-Temperature-Time-Paths. Mineralogical Society of America, Washington, D. C., Monographs, 1995. 799 p. 